\section{Oceanography at Plymouth}

THE marine sciences are an old, if not a venerated, discipline in Britain, but the British Government still seems scarcely aware of their potential importance. Most of the money for research comes from the Natural Environment Research Council, which spent about

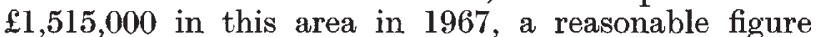
when compared with Britain's GNP, but low for the number of people and the number of establishments doing some work on marine science. What is really needed is some body to coordinate information and research and to encourage greater exchange between research and industry.

One of the few laboratories which actively promotes a closer exchange between scientists in marine biology in Britain and abroad is the Marine Biological Association. The association is an independent research institute with very strong university connexions which receives 95 per cent of its quarter of a million pound budget from the NERC; it has a permanent research staff of only 20 scientists but is host to over 100 visiting research workers during the year and can accommodate 15 to 20 at any one time. The association's laboratory at Plymouth is one of the few research establishments in Britain actually based on the coast - the other principal

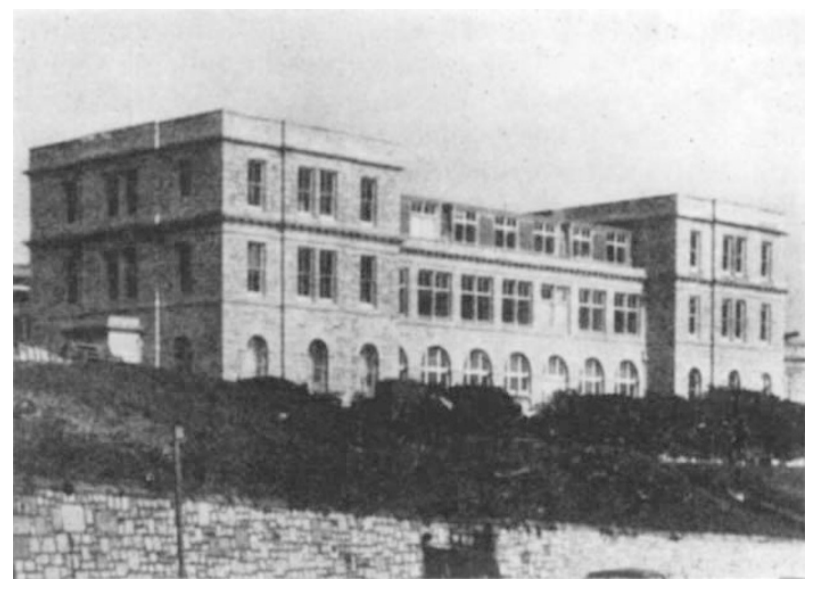

Marine Biological Association Laboratory, Plymcuth.

one is the Scottish Marine Biological Association-and is therefore visited regularly by professors and students who would not otherwise have access to the sea. While the NERC research vessel unit will not remain in Plymouth because of a lack of docking space (Nature, 218, 999; 1968), the association's director, Dr J. E. Smith, is confident that Plymouth will grow as an oceanographic centre, and where the scientists are, the ships will have to call. As a start, the association itself is drawing up preliminary plans for a new 19,000 square foot addition to be built on a two acre site in West Hoe promised by the city of Plymouth. The NERC has already approved the project, and if the Treasury makes funds available the new building should be ready within four years. The main purpose of the addition is to give the association some muchneeded breathing space by placing the teaching rooms, the computer, the big tanks and the ships' workshops and instrumentation there, though a new unit studying inshore hydrography will also be based there. Dr
Smith hopes that these additional facilities will draw scientists from other disciplines, such as physical oceanography.

The association now has four boats, having just taken delivery of a $\mathbf{4 0}$ foot launch for quick trips to and from nearby sites with live material and for reaching grounds that were previously inaccessible. While the largest ship, the $120 \mathrm{ft}$ R.V. Sarsia, is out most of the year on cruises lasting from five to fourteen days, it is badly designed for work and cannot take more than three scientists on any one cruise. The two other ships, the $60 \mathrm{ft}$ Sula and the $30 \mathrm{ft}$ Gammarus, are both used for day collecting trips. A new vessel at least the size of the Sarsia is needed, though the decision rests with the NERC and will be viewed in light of the other boats in the NERC's fleet, used primarily by the universities. In the meantime, space on the various boats is arranged more by individual goodwill than by formal policy; a good system until it breaks down.

The most widely publicized work done by the association during the past year concerned the oil pollution caused by the sinking of the tanker Torrey Canyon. The results of the study have been published by the Cambridge University Press (Nature, 218, 499; 1968). The Torrey Canyon disaster emphasized the weakness of former ecological surveys; there have been no studies so far of entirely pollution-free areas to serve as a basis of comparison. In an attempt to remedy this situation while there is still time, the association plans to study two rivers, the Tamar, which flows into Plymouth and is now relatively unpolluted nearer its source, and the Camel, on the North Devon coast, which Dr Smith thinks is still completely untouched.

\section{Power Struggle}

ThE argument over the cost of generating electricity in Britain has broken out again. The intensification of the struggle between Lord Robens, chairman of the Coal Board, and Sir Stanley Brown of the Central Electricity Generating Board suggests that the decision about the fuel for the proposed power station at Seaton Carew is imminent. Lord Robens claims that an independent inquiry into fuel costs would show that nuclear costs have consistently been underestimated, while the process of streamlining the coal industry has been ignored. By 1970-71, he claimed in a letter to The Times this week, the National Coal Board will have available about 70 million tons of coal at a price of $3 \cdot 25$ pence per therm. Anticipating a little, he made a firm offer to the CEGB to supply coal at this price to fuel Seaton Carew power station. This would produce electricity at a generated cost of about 0.55 pence per kilowatt hour, according to the NCB, against a CEGB estimate of 0.51 pence for a nuclear station. Lord Robens pointed out that nuclear power costs have shown a consistent escalation - Dungeness B, originally to generate electricity at 0.46 pence per kilowatt hour, is now being quoted at 0.57 pence.

In reply, Sir Stanley Brown pointed out that the same considerations also apply to coal fired stations. The cost for Drax, the latest coal fired station, has increased from 0.56 to 0.60 pence per kilowatt hour, and the danger of a further increase in prices is more serious for stations in which fuel makes up a substantial part of the cost. Nuclear stations, with their low fuel 
costs, are relatively insensitive to increases in the cost of fuel. Even at a fuel cost of $3 \cdot 25$ pence per therm, the CEGB argues that a coal fired station would cost $£ 1$ million a year more to run than a nuclear station. If Lord Robens wants to sell coal at 3.25 pence a therm, the CEGB will be only too happy to buy it, to replace much more costly coal it is already burning (see chart).

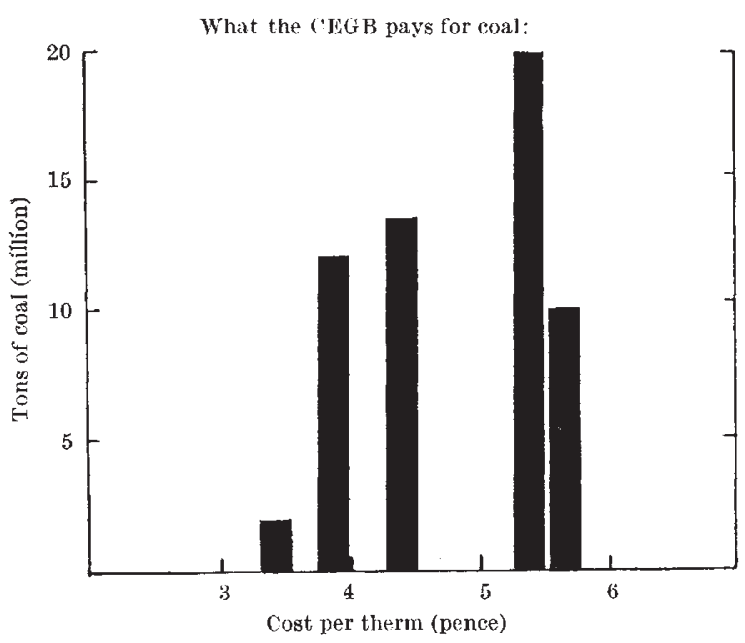

This is why the CEGB is in no mood to take Lord Robens's claims seriously. The great majority of power in Britain will continue to be generated by coal -even by 1972, over 70 per cent of the electricity will be generated by coal. The idea that Seaton Carew is a crucial test case which will determine the future of the coal industry is thus rather facile, if not misleading.

But Lord Robens has found some support from the House of Commons Public Accounts Committee. In its latest report, the committee is critical of the Atomic Energy Authority and the CEGB for the way in which the royalties payable on nuclear gencration have been fixed. For the original magnox stations, which were not expected to be competitive with other sources of power, no royalties were charged. For later magnox stations, which are competitive, it was decided in principle that royalties should be charged, but because of a disagreement between the AEA and the CEGB, the Treasury decided that the magnox royalties should be waived. Instead, the Treasury suggested that a royalty of 0.014 pence per unit of electricity sent out should be paid by the generating board for the AGR stations. The Public Accounts Committee calculates that even on the most optimistic basis possible, this rate of royalty will produce only $£ 26$ million on the present nuclear power programme. The AGR system, according to the AEA, will cost a total of $£ 110$ million to develop, so that the return on the present basis will be less than a quarter of the investment. The committee suggests that this low rate of royalty was in fact designed as an inducement to the CEGB to adopt the AGR, an inducement which it does not think should have been necessary. And in a passage which must have made the mining lobby cheerful, the PAC says that it is not convinced "that the extent to which the cost of generating electricity is being indirectly subsidized by the taxpayer is devoid of economic significance". Put plainly, the PAC thinks the public has been swindled.
The argument, of course, is put less crudely than this The difficulty is to say whether the balance of advantage should lie with the taxpayer or the electricity consumer, two groups which are not always identical. So far, as the PAC points out, the electricity consumer has been favoured. Much depends, of course, on how many more AGR stations are built, but the point is raised even more uncomfortably for the Steam Generating Heavy Water Reactor which the AEA has developed at considerable cost. Unless royalties for this type of reactor are set very much higher than those for the AGR, there seems little chance that the development costs will be recovered. And unless royalties are set at a fair level, it becomes impossible to assess the competing claims of different sources of power. This is playing into Lord Robens's hands.

\section{Eye on the Planets}

IN a revised report on recommended goals for the United States civil space programme after Apollo, the Space Sciences Board of the National Academy of Sciences and the National Research Council has this week (August 15) urged that the exploration of the planets should be given priority and "a substantially increased fraction of the total NASA budget". The present proportion-about 2 per cent of the total NASA budget-is described as "totally inadequate to take advantage of the opportunities available to us". But NASA's interim operating plan, prepared in the light of severe budget cuts this year and also just published, further diminishes what is left of the planetary programme-the Mariner mission to Mars in 1973.

In its 1965 report Space Research-Directions for the Future, the Space Sciences Board recommended that planetary exploration and in particular the search for life should be the main focus of the national space effort in the seventies. The Apollo Applications Programme (AAP) was adopted instead. Now even this has been cut down to two missions by the latest NASA plan, one Saturn I Workshop and one Apollo Telescope Mount. Production of Saturn I and Saturn $V$ vebicles is to stop. This means there will be an inevitable time gap in the programme if Congress later reviews its position. Rather less than half ( $\$ 140$ million) of the amount requested ( $\$ 300$ million) has been made available for AAP in the 1969 budget. The 1973 Mars mission is being sharply reduced in size and scope to match its reduced funds. The landing instrument package and its scientific return will be "substantially less" than originally envisaged in this year's approach to Congress. But the NASA efforts on Apollo, on space applications and on advanced aeronautics are virtually untouched.

In contrast, the Space Sciences Board wishes to see a diversion of funds from manned missions, and disagrees with proposals that the next major space goal should be to place a man on a planet, presumably Mars. Fully automated systems are developing so rapidly that probe technology should be capable of answering the major scientific questions that we can now pose about the planets without intervention on the spot by man. "While at some time in the future it may be in the national interest to undertake a manned programme to the planets, we do not believe man is essential for scientific planetary investigation at this stage." In 